УДК 351.816(470.342)"186/191"(045)

\title{
М.Л. Шмыкова
}

\section{ВЯТСКАЯ УЕЗДНАЯ ЗЕМСКАЯ ПОЧТА: ОРГАНИЗАЦИЯ И СПЕЦИФИКА РАБОТЫ В КОНЦЕ 60-Х ГОДОВ ХІХ - НАЧАЛЕ ХХ ВЕКА}

\begin{abstract}
Вятская уездная земская почта была создана в декабре 1868 г. в результате передачи сельской почты из ведения полиции в ведение земской управы. Создание земской почты было обусловлено необходимостью налаживания постоянной связи между Вяткой и сельской местностью, где отсутсвовали государственные почтовые отделения. Территория Вятского уезда была разделена на два почтовых участка, которые земские почтальоны объезжали. Период становления вятской земской почты пришёлся на конец 1860-х — начало 1870-х гг. Количество пересылаемой простой корреспонденции было тогда невелико. Быстрые темпы развития вятской земской почты наблюдались в 1890-е - начале 1900-х гг. Существенно выросли объёмы пересылаемых частных писем, периодической печати, посылочной, заказной и денежной корреспонденции. Вятское уездное земство было заинтересовано в развитии государственной почты в целях снижения нагрузки на земский бюджет и расширения доступности почтовой связи. В 1910-1912 гг. Вятская земская управа разработала проект расширения сети учреждений государственной почты при финансовой поддержке земства, реализация которого позволила ликвидировать вятскую уездную земскую почту в августе 1913 г.
\end{abstract}

Ключевые слова: Вятский уезд, земское собрание, земская управа, почтовая связь, земская почта.

DOI: $10.35634 / 2412-9534-2020-30-1-48-57$

К. В. Базилевич, автор монографического исследования, посвящённого истории земских почт в России, отмечал, что «наибольшее развитие земская почта получила в губерниях, бедных государственными почтовыми учреждениями, т. е., главным образом, в северных и восточных» [1, с. 55]. Среди губерний, где почта, организованная земствами, получила широкое распространение, исследователь выделил Вятскую, Пермскую, Вологодскую, Самарскую, Новгородскую и Казанскую. В Вятской губернии земская почта существовала во всех 11 уездах, в т. ч. - Вятском. Специальные исследования, посвящённые изучению деятельности Вятского уездного земства в области развития почтовой связи не проводились, что побуждает изучить земский опыт в области развития почтовой связи в центральном густонаселённом уезде Вятской губернии, занимавшем самую маленькую площадь среди других уездов губернии, - 5224 кв. версты.

В 1868 г. численность населения Вятского уезда составляла 188729 чел. В основном уезд был населён русскими крестьянами, жившими в небольших селениях. В это время в Вятском уезде не было ни одного населённого пункта, за исключением губернского города, численность населения которого превышала бы 500 душ мужского пола [24, отд. V, с. 76]. По данным Всероссийской переписи 1897 г., в Вятском уезде проживало 192208 чел. при самой высокой в губернии плотности населения - 36,79 чел. на кв. версту [25, с. 1$]$.

Вятский уезд был важным центром развития кустарной промышленности губернии: здесь многие населённые пункты, особенно расположенные вблизи губернского города, специализировались на производстве какой-либо продукции. В Вятском уезде крестьяне изготавливали льняные ткани. Широкое распространение получили деревообрабатывающие промыслы. Продукция мебельного производства и экипажи продавались далеко за пределами Вятской губернии. Вятские мастера в большом количестве производили посуду и бочки, которые приобретали винокуренные и дегтярные заводы Урала и Сибири. Плотники Вятского уезда были востребованы на всей территории губернии. Среди других отхожих промыслов необходимо выделить бурлачество и извоз [28, с. 106-107]. Вблизи от Вятки располагались небольшие кожевенные заводы. Трижды в год здесь собирались ярмарки (Великорецкая, Семёновская и Никольская), на которых местные крестьяне продавали свою продукцию.

В 1783 г., через три года после учреждения Вятского наместничества, в Вятке была открыта почтовая экспедиция во главе с почтмейстером секунд-майором Треборном, кандидатуру которого рекомендовал вятский генерал-губернатор А. А. Ступишин [4, ф. 583, оп. 3, д. 172, л. 1-2]. В 1830 г. в Вятке вместо губернского почтамта была учреждена губернская почтовая контора, подчинившая себе уездные почтовые конторы. В первой половине XIX в. оформилась система почтовых трактов Вятской губернии, часть которых проходила через Вятский уезд и губернский город. С запада на восток 
Вятскую губернию пересекал Санкт-Петербургско-Пермский почтовый тракт. От города Орлова (Вятской губернии) до Вятки по этому тракту двигались также почты и проезжающие из Москвы и Нижнего Новгорода. С юга на север через территорию Вятского уезда пролегал Вятско-Уфимский почтовый тракт. В 1837 г. по специальному расписанию началось регулярное движение почты два раза в неделю из Санкт-Петербурга в Вятку через Ярославль и Кострому, а также из Москвы в Тобольск [4, ф. 203, оп. 1, д. 238, л. 40-47об]. В 1867 г. в Вятке были установлены почтовые ящики для писем в штемпельных конвертах и с почтовыми марками [4, ф. 203, оп. 1, д. 140, л. 139]. Однако на территории Вятского уезда на почтовых трактах и тем более - за их пределами на коммерческом Кукарском тракте и просёлочных дорогах не было государственных почтовых учреждений. Кроме того, отсутствовали почтовые станции с приёмом и отправкой частной корреспонденции, поэтому населению уезда приходилось преодолевать путь до Вятки, чтобы отправить почту.

В Российской империи попытка наладить регулярную почтовую связь с населёнными пунктами, расположенными вдали от почтовых контор, была предпринята ещё в 1830-1840-е гг. В 1837 г. при земских судах для доставки в сельскую местность служебной корреспонденции и поддержания постоянного срочного сообщения государственных служащих со становыми приставами была организована специальная земская или сельская почта. Согласно «Положению о земской почте», прилагавшемуся к ст. 217 Устава о земских повинностях, она должна была отправляться из уездного города один раз в неделю на следующий день после получения корреспонденции из губернского центра. Перед отправлением все пакеты запечатывались и записывались в особой рассыльной книге. Смена лошадей происходила на станциях, содержателями которых на торгах заключалось соглашение о предоставлении пароконных подвод для следования земской почты. По прибытии на место назначения рассыльный вручал бумаги становым приставам, забирал у них корреспонденцию и возвращался в город, предоставляя земскому исправнику реестры, в которых должностные лица расписывались о выдаче и получении бумаг. В свою очередь пакеты, предназначенные местной администрации, священникам, помещикам, находившимся в ведении станового пристава, передавались адресатам через сотских. В должностные обязанности станового пристава входил также контроль над уравнительным отбыванием местным крестьянским населением натуральной повинности по содержанию подвод для нужд земской почты. Общее наблюдение за исправностью земского почтового сообщения возлагалось на становых приставов и земских исправников [26, с. 522-523]. В 1862 г. земская почта была передана в ведение полицейских управлений и сохранялась в пореформенный период в тех губерниях, где земские учреждения не были введены. В некоторых уездах полицейской земской почтой пользовалось и местное население, но её работа не удовлетворяла растущих потребностей по пересылке частной корреспонденции. В инстанциях письма часто ждали оказии для пересылки на место назначения, терялись, что вызывало недовольство и сельского населения, и полиции, не считавшей себя обязанной заниматься перевозкой частной корреспонденции [1, с. 1-7].

В Вятском уезде сельская почта также работала при полицейских правлениях. В частности, один раз в неделю из Вятки почта отправлялась приставу второго стана, квартира которого находилась в с. Вожгалы, а вместе с ней пересылалась корреспонденция для 11 волостных правлений Вятского уезда. Квартира станового пристава первого участка находилась в самой Вятке, поэтому письма передавались ему по мере поступления, а он в свою очередь рассылал их в 9 волостных правлений через сотских и десятских [4, ф. 617, оп. 1, д. 37, л. 2-2об].

В 1867 г. в Вятской губернии появились земские учреждения. В июле 1867 г. члены Вятской уездной земской управы обсудили с уездным исправником, заинтересованным в быстрой доставке писем в волостные правления, вопрос об улучшении работы сельской почты. Совместными усилиями земства и полиции был введён новый порядок пересылки корреспонденции по Вятскому уезду. Он предусматривал, чтобы рассыльный, отправлявшийся к приставу второго стана, оставлял письма по пути своего следования в волостных правлениях, а последние были обязаны передавать полученные пакеты в близлежащие правления. Однако скорость доставки писем в город оставалась низкой. Корреспонденция, адресованная земству, доходила из волостей за две недели, хотя самое отдалённое волостное правление находилось от Вятки на расстоянии 90 вёрст [4, ф. 617, оп. 1, д. 37, л. 15-18, 50-52].

28 декабря 1868 г. Вятская уездная управа приняла новые правила работы уездной земской почты. Согласно правилам почта должна была отправляться не из полицейского правления, как ранее, а из земской управы два раза в неделю: по понедельникам и пятницам - в два района со специальными рассыльными. Первый район охватывал Пластининское, Вязовское, Щербининское, Троицкое, Югрин- 
ское, Пасеговское, Кстининское, Якимовагинское, Нагорское, Поповское волостные правления, через которые проезжал почтальон земской почты и затем возвращался в Вятку. Общая протяжённость маршрута по первому району составляла 217 вёрст. Маршрут второго почтальона пролегал через Кстининское волостное правление и Швецовскую станцию, а затем через Пальчинское, Вожгальское, Якшинское, Сулаевское, Киселёвское, Рохинское, Филиповское, Поломское, Салтыковское волостные правления и завершался в Вятке. Длина второго кольцевого пути достигала 190 вёрст. Скорость движения почты должна была составлять (в зависимости от времени года и состояния дорог) от 6 до 9 вёрст в час. Земская управа наняла двух почтальонов. Их жалованье в 1869-1870 гг. составляло 8 руб. в месяц, а с 1871 г. - 10 руб. Кроме того, Вятская уездная земская управа планировала начать платный приём писем частных лиц и пересылки периодической печати. Стоимость марки земской почты должна была составить 2 коп., пересылки ежедневных изданий - 1 руб. в год, журналов и газет, выходящих не чаще 1 раза в месяц, - 25 коп. в год [4, ф. 617, оп. 1, д. 37, л. 52-57; 27, с. 425$].$

Несмотря на принятое управой постановление, Вятскому уездному земству не удалось организовать платную пересылку частной корреспонденции. 3 сентября 1870 г. Почтовый департамент МВД утвердил правила работы земской почты, согласно которым российским земствам разрешалось участвовать в доставке писем частных лиц из государственных почтовых учреждений при условии получения приговоров сельских обществ и покупки ими годовых почтовых билетов стоимостью 1 руб. 43 коп. серебром [4, ф. 582, оп. 108, д. 170, л. 48]. При наличии годового билета почтовая контора выдавала почтальону земской почты корреспонденцию частных лиц для дальнейшей доставки в уезд. В 1871 г. Вятская уездная земская управа собрала 12 приговоров волостных сходов, в которых крестьяне высказались против доставки им писем из почтовой конторы из-за высокой стоимости почтовой пересылки. В приговорах указывалось, что «селения... находятся в весьма близком расстоянии от Вятки», а их «жители бывают каждый торговый день в Вятке» и «могут получать письма в конторе сами», учитывая, что «поступает корреспонденция в весьма небольшом количестве» $[4$, ф. 617 , оп. 1 , д. 424, л. 6-14об]. 31 октября 1871 г. Почтовый департамент МВД заменил покупку годовых билетов на двухкопеечный сбор за каждое частное письмо, посылку и повестку, выдаваемую государственным почтовым учреждением для дальнейшей пересылки по земской почте в уезд [4, ф. 582, оп. 108, д. 170, л. 150-150об; ф. 617, оп. 1, д. 424, л. 19-19об]. В таких условиях вводить плату за пересылку частной корреспонденции по сельской почте Вятскому земству не представлялось возможным.

В 1872 г. двухкопеечный сбор был отменён, что поспособствовало активизации работы земской почты, услуги которой стали набирать популярность среди местного населения. Губернский статистик Н. А. Спасский писал: «можно надеяться, что время приучит крестьян ценить удобства, которые они могут получать от земской почты: данные показывают, что число частных писем в 1874 г. в Вятском уезде было переслано по земской почте против 1869 г. почти в 173 раза более» [28, с. 152-153]. В 1871 г. по земской почте Вятского уезда было переслано 11843 пакета, из них 2641 пакет и 3 повестки приняты из Вятской почтовой конторы для пересылки в уезд [4, ф. 582, оп. 108, д. 377, л. 27]. В течение 1874 г. через земскую почту Вятского уезда прошло 2893 частных письма, 21649 казённых пакетов, 147 частных и казённых посылок и 1121 повестка на получение корреспонденции. Как видим, в структуре отправлений доминировали казённые письма, пересылка которых в 7,5 раз превышала пересылку простых частных отправлений. Кроме того, через земскую почту доставлялось 21 периодическое издание для 188 подписчиков, проживавших на территории Вятского уезда, среди которых были и должностные, и частные лица. Наиболее популярной была региональная пресса: по числу подписчиков с большим отрывом лидировали «Вятские губернские ведомости» (63 подписчика) и «Вятские епархиальные ведомости» (36 подписчиков) [4, ф. 617, оп. 2, д. 701, л. 4-5].

В 1870-1880-х гг. маршруты вятской земской почты неоднократно менялись. В 1890-е гг. первый почтовый участок охватывал 8 волостных правлений. По размерам он был значительно меньше второго участка, в который, помимо 14 волостных правлений, входили также квартиры становых приставов, земских начальников, участковых врачей и благочинных. Обширные размеры работы второго участка приводили к сбоям в работе земской почты. Почтальон, вернувшись из поездки по второму участку, не успевал разнести корреспонденцию по городу и отправлялся с почтой в волостные правления первого участка, откладывая доставку корреспонденции в Вятке до своего возвращения. В связи с этим, в 1897-1898 гг. управа безуспешно предлагала гласным уездного собрания выделить средства для найма третьего почтальона и разделить второй участок земской почты на два района, что позволило бы отправлять почту два раза в неделю в течение всего года. Только в 1901 г. был на- 
Вятская уездная земская почта: организация и специфика работы...

нят третий почтальон для доставки корреспонденции по губернскому городу $[5$, с. 519-520; 6 , с. 40 , $350-351 ; 27$, c. $426-428]$.

В конце XIX - начале XX в. особую актуальность и остроту приобрела проблема доставки корреспонденции в сельской местности до её непосредственных адресатов. В 1902 г. Вятская губернская управа организовала совещание председателей уездных земских управ, на котором уездным земствам было рекомендовано выделить по 25 руб. каждому волостному правлению на ведение почтовых операций. Вятская уездная земская управа предложила земскому собранию выбрать в каждой волости надёжного и грамотного крестьянина, который бы за плату от земства, не превышающую 60 руб. в год, объезжал сёла на своей лошади и доставлял почту. Однако земское собрание не поддержало управу из-за дороговизны проекта [7, с. 366-367; 8, с. 75, 474-475]. В 1905 г. Вятское уездное земское собрание вернулось к проблеме земских почтовых маршрутов, поскольку с развитием системы начального образования их несовершенство становилось всё более очевидным. 17 сёл Вятского уезда, где к тому времени работали земские школы, оставались без почтовой связи, что затрудняло доставку учебников и пособий. Управа предлагала два пути решения проблемы. Первый предполагал увеличение протяжённости пути следования почты и влёк за собой существенный рост расходов на её содержание за счёт найма почтальонов и доставки почты на земских лошадях. Согласно второму варианту, на осуществлении которого в силу его простоты и дешевизны настаивала управа, предполагалось возложить на содержателей земских станций подвоз корреспонденции в сёла, где работали земские училища. При реализации этого проекта дополнительные затраты Вятского уездного земства на выплаты содержателям земских станций должны были составить 500 руб. в год. Вятское уездное земское собрание отклонило оба варианта, обязав сельских почтальонов заезжать в земские училища, находившиеся на пути следования земской почты [27, с. 429-430]. Таким образом, ограниченность бюджета не позволяла земцам активно развивать почтовую связь.

Сельская почта содержалась за счёт земского сбора и была убыточной. Самые значительные траты были на перевозку почты, однако земством они специально не просчитывались и были заложены в общие расходы на содержание земских станций. На рубеже XIX-XX вв. Вятское уездное земство содержало 24 земские станции с 96-98 парами лошадей и выделяло на эти цели более 32 тыс. руб. ежегодно [20, с. 14]. В 1880-е - первой половине 1890-х гг. Вятское и Елабужское земства стояли на последнем месте в Вятской губернии по затратам на содержание сельской почты. Расходы Вятского земства на почту в этот период в среднем составляли $0,4 \%$ бюджета [3, с. 8]. Непосредственно в смете расходов закладывались средства на выплату жалования почтальонам, которое выросло в течение конца XIX - начала XX в. со 180 до 300 руб. в год. Именно такое жалование получало большинство земских почтальонов в Вятской губернии. Кроме того, Вятское уездное земство закупало канцелярские принадлежности, чемоданы, верхнюю одежду для почтальонов и револьверы.

7 октября 1897 г. Вятское уездное земское собрание одобрило предложение управы ввести плату за пересылку по земской почте простых частных писем. Вятская уездная земская управа предлагала воспользоваться опытом Сарапульского земства и напечатать земские марки в Экспедиции заготовления государственных бумаг в Санкт-Петербурге [5, с. 520-521]. Однако первые марки вятской земской почты были заказаны, вероятно, в местной типографии. В 1898 г. за печать 105000 марок управа заплатила 105 руб. Кроме того, земцы приобрели ряд вещей, необходимых для организации платной пересылки писем, - печати для гашения марок, почтовые ящики для простых писем, шкатулки для хранения марок, штемпели с переводными числами [23, с. 170]. 1 февраля 1898 г. управа и волостные правления Вятского уезда начали продажу марок земской почты, и за первые полгода со времени введения оплаты было продано марок вятской земской почты на сумму 157 руб. 90 коп. С 1905 г. марки вятской земской почты стали заказываться в столице.

Особую сложность вызывала оплата земского почтового сбора с писем, поступивших из Вятской почтовой конторы через земскую почту в волостные правления. Для оплаты пересылки крестьяне вызывались в волостные правления специальными повестками и не спешили преодолевать расстояния в 10 и более вёрст, чтобы получить письмо. Некоторые земские гласные ещё в 1900 г. предлагали отменить этот сбор. С 1 января 1907 г. письма частных лиц, оплаченные казёнными почтовыми марками, освобождались от земского почтового сбора. Кроме того, уездная управа отказалась от доставки таких писем адресатам в губернском городе. Эти письма передавались с земской почты в Вятскую почтовую контору и оплачивались по тарифам казённой почты [21, с. 17-18; 27, с. 429-430]. Новые правила повлекли за собой сокращение поступлений в земский бюджет от продажи почтовых марок. Если в 1904- 
1906 гг. доходы Вятского земства от продажи марок составляли 251 руб., 202 руб. 60 коп. и 202 руб. 50 коп. соответственно, то в 1907 г. - 73 руб. [19, с. $19 ; 20$, с. $15 ; 21$, с. 14; 22, с. 18].

Среди других доходов земской почты необходимо отметить поступления от пересылки денежных пакетов и посылок. В 1901 г. Вятское уездное земство ввело их платную доставку первоначально в виде эксперимента на один год. Земские почтальоны вносили в управу из своего жалования 3 руб. как залог на случай потери перевозимых посылок и денежных сумм. Деньги для пересылки принимались и от частных лиц, и от учреждений, за исключением Вятской почтовой конторы и уездного казначейства. Размер пересылаемых сумм частных лиц был ограничен 100 руб. Эти деньги могли быть адресованы волостным правлениям, должностным лицам и государственным учреждениям, кроме почтовой конторы и уездного казначейства. Тариф за пересылку составлял 0,5 коп. с каждого рубля. Бесплатно пересылались деньги учителей народных училищ и крестьян, отправлявших их в волостные правления без дальнейшей передачи третьему лицу. Вес посылок был ограничен 20 фунтами, а ценность -25 руб. Стоимость доставки составляла 10 коп. [17, с. 12]. Доля посылок среди всей корреспонденции, доставленной по вятской земской почте в 1890-1900-е гг., росла, но не превысила $1 \%$, денежные отправления составляли не более 2,4 \%, заказные письма - не более $2 \%$ (табл.).

Количество корреспонденции, пересланной по вятской уездной земской почте в 1892-1911 гг.

\begin{tabular}{|c|c|c|c|c|c|c|c|c|}
\hline \multirow[t]{2}{*}{ Год } & \multicolumn{2}{|c|}{1892} & \multicolumn{2}{|c|}{1898} & \multicolumn{2}{|c|}{1904} & \multicolumn{2}{|c|}{1911} \\
\hline & Шт. & $\%$ & шт. & $\%$ & шт. & $\%$ & шт. & $\%$ \\
\hline Казённые письма & 39320 & 47,8 & 56521 & 52 & 103768 & 43,4 & 44704 & 33,8 \\
\hline Частные письма & 14782 & 18 & 10831 & 9,97 & 22862 & 9,55 & & \\
\hline Денежные пакеты & 584 & 0,7 & 1306 & 1,2 & 4047 & 1,7 & 3138 & 2,4 \\
\hline Заказные отправления & 23 & 0,03 & 1428 & 1,3 & 2867 & 1,2 & 2640 & 2 \\
\hline Посылки & 432 & 0,52 & 939 & 0,9 & 1018 & 0,43 & 248 & 0,2 \\
\hline Периодика & 21390 & 26 & 30150 & 27,8 & 83875 & 35 & 67861 & 51,4 \\
\hline Бандероли & 620 & 0,8 & 4596 & 4,2 & 17096 & 7,1 & 6399 & 4,8 \\
\hline Телеграммы & 39 & 0,05 & 33 & 0,03 & 40 & 0,02 & 66 & 0,05 \\
\hline Повестки казённой почты & 5018 & 6,1 & 1661 & 1,5 & 2779 & 1,2 & 6912 & 5,25 \\
\hline $\begin{array}{c}\text { Пакеты казённой почты } \\
\text { волостным правлениям }\end{array}$ & - & - & 1146 & 1,1 & 1000 & 0,4 & 150 & 0,1 \\
\hline Всего & 82208 & 100 & 108611 & 100 & 239352 & 100 & 132118 & 100 \\
\hline Всего отправлено в уезд & 63434 & 77,2 & 83959 & 77,3 & 190656 & 79,7 & 103485 & 78,3 \\
\hline Всего получено из уезда & 18774 & 22,8 & 24652 & 22,7 & 48796 & 20,3 & 28633 & 21,7 \\
\hline
\end{tabular}

Cocm. no: $[9$, c. $1090 ; 13$, c.; $24-25 ; 16$, c. $19 ; 19$, c. 19].

Структура почтовых отправлений вятской земской почты существенно не отличалась от структуры других уездных земских почт Вятской губернии. Основную массу составляла корреспонденция, пересылаемая из города в волости. В конце XIX - начале XX вв. её доля незначительно выросла и варьировалась в пределах 77-80 \% (табл.). Остальная корреспонденция доставлялась из волостных правлений в Вятку. Среди видов отправлений длительное время лидировали казённые простые письма, удельный вес которых в отдельные годы превышал половину всей корреспонденции. При этом значительную массу казённых простых писем составляла корреспонденция самой управы. Например, из 2679 казённых писем, отправленных из Вятки в волостные правления в 1911 г., 2088 пакетов принадлежали земской управе [9, с. 1090]. Данное обстоятельство свидетельствует о том, что именно земская почта позволяла органам местного самоуправления решать возложенные на них задачи и являлась важным каналом взаимодействия органов государственной власти, земства с общинными институтами. Падение доли частных писем в структуре отправлений во второй половине 1890 -х гг. объясняется тем, что десяти волостным правлениям Вятского уезда были разрешены государственные почтовые операции (продажу марок государственной почты, приём и выдачу простой корреспонденции). Корреспонденция, принятая в таких волостных правлениях, запаковывалась в отдельные пакеты, подлежала специальному учёту, хотя и перевозилась по земской почте. Кроме того, в начале 1890-х гг. среди крестьян Вятского уезда наблюдалось сокращение отхожих промыслов за пределы уезда. Развитие кустарной промышленности, поиск крестьянами дополнительных заработков в Вятке - всё это приводило к частым поездкам в губернский город, где можно было отправить письма. 
Вятская уездная земская почта: организация и специфика работы...

Земская почта играла существенную роль в распространении периодической печати, которая пересылалась в Вятском уезде бесплатно. Хотя сведения о количестве подписчиков газет и журналов и их социальном составе в отчётах Вятской уездной земской управы отсутствуют, однако в журналах собраний соседних земств отмечается, что не только «увеличение числа интеллигентных работников... в лице учащихся, медицинского персонала, среди духовенства» повлияло на увеличение частных почтовых пересылок, но и «масса деревенского населения предъявляет усиленные и повышенные требования на печатный материал» [11, с. 28]. Доля периодики в пересылаемой по вятской земской почте корреспонденции выросла с 26 \% в 1892 г. до 51 \% в 1911 г. (табл. 1). Только за период с 1900 по 1905 гг. по вятской земской почте было переслано 349376 экз. газет и журналов. Значимый рост пересылки периодики пришёлся на 1894, 1902 и 1904 гг. Если в 1893 г. подписчикам были доставлены 17961 экз. газет и журналов, то в 1894 г. — уже 39037 экз., т. е. более, чем в 2 раза. В 1901 гг. подписчики Вятского уезда получили 33027 штук газет и журналов, в 1902 г. - 67728 [14, с. 26; 15, с. $23 ; 17$, с. 13; 18, с. 12]. Наибольшее количество периодических изданий было доставлено в 1904 г., т. е. в период начала русско-японской войны и накануне первой русской революции (83875 экз.). В дальнейшем наметился небольшой спад.

Расширился ассортимент подписных изданий: в 1890-е гг. по вятской земской почте доставлялось до полусотни наименований газет и журналов, в 1907 г. их количество достигло 162. Состав периодических изданий увеличился и за счёт центральной прессы, и в связи с появлением новых местных изданий. В частности, с 1894 по 1907 г. земским гласным и служащим, в волостные правления, школы и библиотеки бесплатно рассылалась «Вятская газета» - «первая в России земская народная газета», издававшаяся Вятским губернским земством [12, с. 132, 136-137]. В период революции 1905-1907 гг. в Вятской губернии появилось до 10 газет различной социально-политической направленности, одной из которых стала либерально-демократическая газета «Вятская речь». Её издателем стал Н. А. Чарушин [2, с. 169.]. В связи с пересылкой газеты по сельской почте между Н. А. Чарушиным и Вятским уездным земством возник конфликт. Поводом стала публикация в «Вятской речи» заметки о несвоевременной доставке периодики по вятской земской почте. В ответ в ноябре 1910 г. уездная земская управа постановила отказаться от бесплатной пересылки «Вятской речи»её адресатам. В своём решении управа опиралась на распоряжение Сената от 12 марта 1910 г., согласно которому запрещалось бесплатно распространять по земской почте газеты политического характера. Издатель обратился к земскому собранию с просьбой пересмотреть постановление управы. 7 октября 1911 г. на заседании Вятского земского собрания выступил гласный П. А. Шуравин, который отметил, что данное постановление было вызвано не столько заметкой о земской почте, сколько критикой в газете председателя управы И. И. Храболовича. По мнению гласного, управа должна была вынести вопрос о введении почтового сбора за пересылку периодики на рассмотрение земского собрания, поскольку до инцидента все газеты пересылались по земской почте бесплатно. Земское собрание согласилось с мнением П. А. Шуравина и отменило постановление управы, однако Вятское губернское по земским и городским делам присутствие признало постановление собрания неправомерным, и за пересылку газеты земством стал взиматься сбор в размере 2 коп. [9, с. 1091-1092; 27, с. 432-433].

В начале XX в. Вятское земство приняло активное участие в расширении сети государственных почтовых учреждений, которых в начале 1910-х гг. в уезде было 5: Вятская почтово-телеграфная контора, Куменское почтовое отделение, обслуживавшее также население соседнего Нолинского уезда; железнодорожные почтовые отделения на станциях Ардаши, Просница и Вятка I. В 1910 г. начальник Пермского почтово-телеграфного округа, в ведении которого находились учреждения связи Вятской губернии, предложил уездным земствам распространить опыт земцев Переяславского уезда Полтавской губернии, разделивших уезд на 7 почтовых участков, каждый из которых не превышал 50-60 вёрст и обслуживался своим почтальоном. Почтальон два раза в неделю объезжал все селения, входившие в его участок, и доставлял на дом все виды корреспонденции, принятой из государственных почтовых учреждений, волостей и почтальонов соседних участков. Вятское земство признало данный проект неподходящим для своего уезда, на территории которого находилось 2086 населённых пунктов, в то время как в Переяславском уезде - 108 [9, с. 1085]. Вятское земство предложило свой проект реформирования земской почты в уезде, в ходе реализации которого 1 августа 1913 г. было открыто почтовое отделение в с. Вожгалы и началось производство почтовых операций в 12 волостных правлениях дополнительно к тем волостным правлениям, где они уже велись. Кроме того, земство выделило средства на расширение штата почтальонов государственной почты и перевозку корреспонденции по уезду. Эти мероприятия позволили ликвидировать в августе 1913 г. вятскую земскую почту [10, с. 732-733]. 
Таким образом, опираясь на опыт Вятского уездного земства, можно констатировать, что проведение земской реформы в период правления Александра II существенно повлияло на развитие почтовой связи в российской провинции, способствуя появлению регулярного почтового обмена между расположенными в уездных городах органами государственной власти и местного самоуправления и удалёнными на значительные расстояния от почтовых трактов волостными правлениями. Создание земской почты, обусловленное на начальном этапе нуждами местного управления, в дальнейшем повлекло за собой оживление переписки между частными лицами, своевременную доставку периодической печати, воздействовавшей на формирование общественного мнения; способствовало развитию товарно-денежных отношений. Однако ограниченность бюджета не позволяла земцам расширить деятельность сельской почты без опоры на государственные почтовые учреждения. Государственная почта тоже была заинтересована в реализации совместных с земством проектов развития почтовой связи в сельской местности, что приводило к созданию новых государственных почтовых контор и отделений, организации операций государственной почты при волостных правлениях при финансовой поддержке земства и его участии в перевозке корреспонденции.

\section{СПИСОК ИСТОЧНИКОВ И ЛИТЕРАТУРЫ}

1. Базилевич К. В. Земская почта в России (1865-1917). М.: Связь, 1926.70 с.

2. Вахрушев $A$. A. Просветительская миссия печати и литературы в провинциальной России (на материале Вятской губернии XVII — начала XX веков). Ижевск: Изд-во «Удмуртский университет», 2011. 274 с.

3. Голубев П. А. Историко-статистический сборник сведений по вопросам экономического и культурного развития Вятского края. Вятка: Изд. Вятского губернского земства, 1896. 463 с.

4. Государственный архив Кировской области (ГА КО).

5. Журналы Вятского уездного земского собрания XXXI очередной сессии (с 28 сент. по 8 окт. 1897 г.) с приложениями к ним. Вятка: Тип. Маишева, 1898. 788 с.

6. Журналы Вятского уездного земского собрания XXXII очередной сессии (с 30 сент. по 9 окт. 1898 г.) с приложениями к ним. Вятка: Тип. и хромолитография Маишева, 1899. 426 с.

7. Журналы XXXVI очередной сессии Вятского уездного земского собрания (с 27 сент. по 2 окт.) 1902 года с приложениями к ним. Вятка: Тип. и хромолитография Маишевой, 1903. 395 с.

8. Журналы Вятского уездного земского собрания чрезвычайной сессии 14 авг. и XXXVII очередной (с 27 сент. по 6 окт. 1903 г.) с приложениями к ним. Вятка: Тип. и хромолитография Шкляевой, 1904. 488 с.

9. Журналы Вятского уездного земского собрания 46-й очередной сессии (с 15 нояб. по 1 дек. 1912 г.) с приложениями к ним. Вятка: Тип. и хромолитография Шкляевой, 1913. 1122 с.

10. Журналы Вятского уездного земского собрания чрезвычайной сессии 27 апреля 1913 г. и 47 очередной сессии (15-25 сент.) 1913 г. с приложениями к ним. Вятка: Тип. и хромолитография Шкляевой, 1914. 744 с.

11. Журналы Глазовского уездного земского собрания 46-й очередной сессии с 15 по 29 нояб. 1912 г. с приложениями в ним. Т. 1. Вятка: Тип. и хромолитография Шкляевой, 1913. 594 с.

12. Краткий обзор деятельности Вятского губернского земства за 35 лет (1867-1902 гг.). Вып. 1. Вятка: Изд. Вятского губернского земства, 1906. 276 с.

13. Отчёт Вятской уездной земской управы о деятельности её и состоянии подведомственных ей частей, заведений и имуществ за 1892 г. Вятка: Тип. Маишева, 1893. 109 с.

14. Отчёт Вятской уездной земской управы о деятельности её и состоянии подведомственных ей частей, заведений и имуществ за 1893 г. Вятка: Тип. Маишева, 1894. 101 с., 34 с.

15. Отчёт Вятской уездной земской управы о деятельности её и состоянии подведомственных ей частей, заведений и имуществ за 1894 г. Вятка: Тип. Маишева, 1895. 137 с.

16. Отчёт Вятской уездной земской управы о деятельности её и состоянии подведомственных ей частей, заведений и имуществ за 1898 г. Вятка: Скоропечатня тип. и хромолитография Н. А. Огородникова, 1899. 63 с.

17. Отчёт Вятской уездной земской управы о деятельности её и состоянии подведомственных ей частей, заведений и имуществ за 1901 г. Вятка: Тип. и хромолитография Маишевой, 1902. 47 с., 31 с.

18. Отчёт Вятской уездной земской управы о деятельности её и состоянии подведомственных ей частей, заведений и имуществ за 1902 г. Вятка: Тип. и хромолитография Маишевой, 1903. 40 с., 33 с.

19. Отчёт Вятской уездной земской управы о деятельности её и состояния подведомственных ей частей, заведений и имуществ за 1904 г. Вятка: Тип. и хромолитография Шкляевой, 1905. 115 с.

20. Отчёт Вятской уездной земской управы о деятельности её и состояния подведомственных ей частей, заведений и имуществ за 1905 г. Вятка: Тип. и хромолитография Шкляевой, 1907. 123 с.

21. Отчёт Вятской уездной земской управы о деятельности её и состояния подведомственных ей частей, заведений и имуществ за 1906 г. Вятка: Тип. и хромолитография Шкляевой, 1908. 115 с. 
22. Отчёт Вятской уездной земской управы о деятельности её и состояния подведомственных ей частей, заведений и имуществ за 1907 г. Вятка: Тип. и хромолитография Шкляевой, 1908. 105 с.

23. Отчёт о суммах Вятской уездной земской управы за 1898 г. Вятка: Тип. и хромолитография Маишева, 1899. $201 \mathrm{c}$.

24. Памятная книжка Вятской губернии на 1870 г. Вятка: Тип. губернского правления, 1870. 732 с.

25. Первая всеобщая перепись населения Российской империи / под ред. Н. А. Тройницкого. Т. Х. Вятская губерния. СПб.: Изд. Центрального статистического комитета МВД, 1904. 267 с.

26. Полн. собр. законов Российской империи. Собр. II. Т. 12. Отд. І. СПб.: Тип. ІІ Отделения собств. е.и.в. канцелярии, $1837.822 \mathrm{c}$

27. Сб. постановлений Вятского уездного земства за 48 лет (1867-1914). Т. 1. Вятка: Тип. и хромолитография Шкляевой, 1915. 501 с.

28. Статистическое описание Вятской губернии и справочные сведения / сост. Н. Спасский. Вятка: Губернская типография, $1875.323 \mathrm{c.}$

Поступила в редакцию 28.09.2019

Шмыкова Мария Леонидовна, кандидат исторических наук, доцент кафедры истории России

ФГБОУ ВО «Удмуртский государственный университет»

426034, Россия, г. Ижевск, ул. Университетская, 1 (корп. 2)

E-mail: mlshmykova@inbox.ru

\section{M.L. Shmykova \\ VYATKA DISTRICT ZEMSTVO POST: ORGANIZATION AND SPECIFICS FROM THE LATE 1860s TO THE EARLY 1900S}

DOI: $10.35634 / 2412-9534-2020-30-1-48-57$

Vyatka district zemstvo post was established in December 1868. It was relegated from police supervision to Zemskaya Uprava. Zemstvo post establishment became necessary to connect Vyatka and the countryside. There wasn't the state post in the countryside. Vyatka district territory was divided into two post regions. Each region had postmen. The period of Vyatka zemstvo post establishment peaked in the late $1860 \mathrm{~s}$ - early $1870 \mathrm{~s}$. The amount of simple correspondence was small. Vyatka zemstvo post experienced rapid growth from 1890s to the early 1900s. The number of private letters, periodical press, parcels, registered and money orders increased significantly. Vyatka district zemstvo was interested in the state post development in order to relieve zemstvo budget and increase the availability of postal communications. In 1910-1912s Zemskaya Uprava has developed a project to expand the network of state postal institutions with the financial support of the zemstvo. The project realization allowed eliminating Vyatka district zemstvo post in August 1913.

Keywords: Vyatka district, Zemskoye Sobranye (a representative council), Zemskaya Uprava (an executive board), postal service, zemstvo post.

\section{REFERENCES}

1. Bazilevich K. V. Zemskaja pochta v Rossii (1865-1917). [Zemstvo post in Russia (1865-1917)]. Moscow, "Svjaz" Publ., 1926, 70 p. (In Russian).

2. Vahrushev A. A. Prosvetitel'skaja missija pechati i literatury v provincial'noj Rossii (na materiale Vjatskoj gubernii XVII - nachala XX vekov) [Educational mission of press and literature in provincial Russia (based on material of Vyatka province of the 17th - early 20th centuries]. Izhevsk, Udmurt University Press, 2011, 274 p. (In Russian).

3. Golubev P. A. Istoriko-statisticheskij sbornik svedenij po voprosam jekonomicheskogo i kul'turnogo razvitija Vjatskogo kraja [Historical and statistical collected book on the economic and cultural development of Vyatka region]. Vyatka, Ed. Vyatka provincial zemstvo, 1896, 463 p. (In Russian).

4. Gosudarstvennyj arhiv Kirovskoj oblasti [The State Archive of Kirov Region]. (in Russian, unpublished).

5. Zhurnaly Vjatskogo uezdnogo zemskogo sobranija XXXI ocherednoj sessii (s 28 sentjabrja po 8 oktjabrja 1897 g.) s prilozhenijami k nim [Journals of Vyatka district zemstvo assembly of the XXXI regular session (from September 28 to October 8, 1897) with annexes]. Vyatka, Print. house of Maishev, 1898, 788 p. (In Russian).

6. Zhurnaly Vjatskogo uezdnogo zemskogo sobranija XXXII ocherednoj sessii (s 30 sentjabrja po 9 oktjabrja 1898 g.) s prilozhenijami k nim [Journals of Vyatka district zemstvo assembly of the XXXII regular session (from September 30 to October 9, 1898) with annexes]. Vyatka, Print. house of Maishev, 1899, 426 p. (In Russian) 
7. Zhurnaly XXXVI ocherednoj sessii Vjatskogo uezdnogo zemskogo sobranija (s 27 sentjabrja po 2 oktjabrja) 1902 goda s prilozhenijami $\mathrm{k}$ nim [Journals of the XXXVI regular session of Vyatka district zemstvo assembly (from September 27 to October 2), 1902, with annexes]. Vyatka, Print. house of Maishev, 1903, 395 p. (In Russian).

8. Zhurnaly Vjatskogo uezdnogo zemskogo sobranija chrezvychajnoj sessii 14 avgusta i XXXVII ocherednoj (s 27 sentjabrja po 6 oktjabrja 1903 g.) s prilozhenijami k nim [Journals of Vyatka district zemstvo assembly of the emergency session on August 14 and the XXXVII regular session (from September 27 to October 6, 1903) with annexes]. Vyatka, Print. house of Shklyaeva, 1904, 488 p. (In Russian).

9. Zhurnaly Vjatskogo uezdnogo zemskogo sobranija 46-j ocherednoj sessii (s 15 nojabrja po 1 dekabrja 1912 g.) s prilozhenijami k nim [Journals of Vyatka district zemstvo assembly of the 46th regular session (from November 15 to December 1, 1912) with annexes]. Vyatka, Print. house of Shklyaeva, 1913, 1122 p. (In Russian).

10. Zhurnaly Vjatskogo uezdnogo zemskogo sobranija chrezvychajnoj sessii 27 aprelja 1913 g. i 47 ocherednoj sessii (15-25 sentjabrja) $1913 \mathrm{~g}$. s prilozhenijami k nim. [Journals of Vyatka district zemstvo assembly of the emergency session on April 27, 1913 and the 47th regular session (September 15-25) 1913 with their annexes]. Vyatka, Print. house of Shklyaeva, 1914, 744 p. (In Russian).

11. Zhurnaly Glazovskogo uezdnogo zemskogo sobranija 46-j ocherednoj sessii s 15 po 29 nojabrja 1912 g. s prilozhenijami v nim [Journals of Glazov district zemstvo assembly of the 46th regular session from November 15 to November 29, 1912 with their annexes]. Vol. 1. Vyatka, Print. house of Shklyaeva, 1913, 594 p. (In Russian).

12. Kratkij obzor dejatel'nosti Vjatskogo gubernskogo zemstva za 35 let (1867-1902 gg.) [Brief review of the activities of Vyatka provincial zemstvo for 35 years (1867-1902)]. Vol. 1. Vyatka, Ed. Vyatka provincial zemstvo, 1906, 276 p. (In Russian).

13. Otchet Vjatskoj uezdnoj zemskoj upravy o dejatel'nosti ee i sostojanii podvedomstvennyh ej chastej, zavedenij i imushhestv za $1892 \mathrm{~g}$. [The report of Vyatka district zemstvo council on its activities and its subordinate units, establishments and property condition for 1892].Vyatka, Print. house of Maishev, 1893, 109 p. (In Russian).

14. Otchet Vjatskoj uezdnoj zemskoj upravy o dejatel'nosti ee i sostojanii podvedomstvennyh ej chastej, zavedenij i imushhestv za $1893 \mathrm{~g}$. [The report of Vyatka district zemstvo council on its activities and its subordinate units, establishments and property condition for 1893]. Vyatka, Print. house of Maishev, 1894, 101 p., 34 p. (In Russian).

15. Otchet Vjatskoj uezdnoj zemskoj upravy o dejatel'nosti ee i sostojanii podvedomstvennyh ej chastej, zavedenij i imushhestv za $1894 \mathrm{~g}$. [The report of Vyatka district zemstvo council on its activities and its subordinate units, establishments and property condition for 1894]. Vyatka, Print. house of Maishev, 1895, 137 p. (In Russian).

16. Otchet Vjatskoj uezdnoj zemskoj upravy o dejatel'nosti ee i sostojanii podvedomstvennyh ej chastej, zavedenij i imushhestv za $1898 \mathrm{~g}$. [The report of Vyatka district zemstvo council on its activities and its subordinate units, establishments and property condition for 1898]. Vyatka, Print. house of Ogorodnikov, 1899, 63 p., 63 p. (In Russian).

17. Otchet Vjatskoj uezdnoj zemskoj upravy o dejatel'nosti ee i sostojanii podvedomstvennyh ej chastej, zavedenij i imushhestv za $1901 \mathrm{~g}$. [The report of Vyatka district zemstvo council on its activities and its subordinate units, establishments and property condition for 1901]. Vyatka, Print. house of Maisheva, 1902, 47 p., 31 p. (In Russian).

18. Otchet Vjatskoj uezdnoj zemskoj upravy o dejatel'nosti ee i sostojanii podvedomstvennyh ej chastej, zavedenij i imushhestv za $1902 \mathrm{~g}$. [The report of Vyatka district zemstvo council on its activities and its subordinate units, establishments and property condition for 1902]. Vyatka, Print. house of Maisheva, 1903, 40 p., 33 p. (In Russian).

19. Otchet Vjatskoj uezdnoj zemskoj upravy o dejatel'nosti ee i sostojanija podvedomstvennyh ej chastej, zavedenij i imushhestv za $1904 \mathrm{~g}$. [The report of Vyatka district zemstvo council on its activities and its subordinate units, establishments and property condition for 1904]. Vyatka, Print. house of Shklyaeva, 1905, 115 p. (In Russian).

20. Otchet Vjatskoj uezdnoj zemskoj upravy o dejatel'nosti ee i sostojanija podvedomstvennyh ej chastej, zavedenij i imushhestv za $1905 \mathrm{~g}$. [The report of Vyatka district zemstvo council on its activities and its subordinate units, establishments and property condition for 1905]. Vyatka, Print. house of Shklyaeva, 1907, 123 p. (In Russian).

21. Otchet Vjatskoj uezdnoj zemskoj upravy o dejatel'nosti ee i sostojanija podvedomstvennyh ej chastej, zavedenij i imushhestv za $1906 \mathrm{~g}$. [The report of Vyatka district zemstvo council on its activities and its subordinate units, establishments and property condition for 1906]. Vyatka, Print. house of Shklyaeva, 1908, 115 p. (In Russian).

22. Otchet Vjatskoj uezdnoj zemskoj upravy o dejatel'nosti ee i sostojanija podvedomstvennyh ej chastej, zavedenij i imushhestv za $1907 \mathrm{~g}$. [The report of Vyatka district zemstvo council on its activities and its subordinate units, establishments and property condition for 1907]. Vyatka, Print. house of Shklyaeva, 1908, 105 p. (In Russian).

23. Otchet o summah Vjatskoj uezdnoj zemskoj upravy za $1898 \mathrm{~g}$. [The report on the amounts of Vyatka district council for 1898]. Vyatka, Print. house of Maishev, 1899, 201 p. (In Russian).

24. Pamjatnaja knizhka Vjatskoj gubernii na 1870 g. [The memorial book of Vyatka province for 1870]. Vyatka, Print. house of the provincial government, 1870, 732 p. (In Russian).

25. Pervaja vseobshhaja perepis' naselenija Rossijskoj imperii / pod red. N. A. Trojnickogo [The First General Census of the Population of the Russian Empire. Ed. N. A. Troitsky]. Vol. X. St. Petersburg, Publ. Central Statistical Committee of the Ministry of Internal Affairs, 1904, 267 p. (In Russian).

26. Polnoe sobranie zakonov Rossijskoj imperii [The complete collection of laws of the Russian Empire]. Col. II. Vol. 12. Part I. St. Petersburg, Print. house of the II Division of property. e.i.v. Chancellery, 1837, 822 p. (In Russian). 
27. Sbornik postanovlenij Vjatskogo uezdnogo zemstva za 48 let (1867-1914) [The collection of resolutions of the Vyatka district zemstvo for 48 years (1867-1914).]. Vol. 1. Vyatka, Print. house of Shklyaeva, 1915, 501 p. (In Russian).

28. Statisticheskoe opisanie Vjatskoj gubernii i spravochnye svedenija / sost. N. Spasskij [Statistical description of the Vyatka province and reference information]. Vyatka, Provincial Print. House, 1875, 323 p. (In Russian).

Received 28.09.2019

Shmykova M. L., Candidate of Historiy, Associate Professor of the Department of Russian History Udmurt State University

Universitetskaya st., 1/2, Izhevsk, Russia, 426034

E-mail: mlshmykova@inbox.ru 